\title{
A right-to-left policy switch? An analysis of the Honduran case under Manuel Zelaya
}

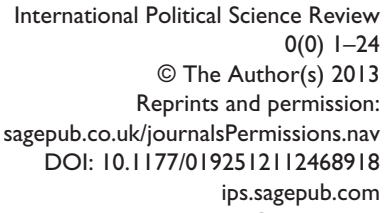

International Political Science Review $0(0) 1-24$

(C) The Author(s) 2013 Reprints and permission: sagepub.co.uk/journalsPermissions.nav DOI: $10.1177 / 0192512112468918$ ips.sagepub.com

(SAGE

\section{Clayton M. Cunha Filho, André Luiz Coelho and Fidel I. Pérez Flores}

\begin{abstract}
A member of the Honduran elite and elected president with a right-of-center platform in 2005, Manuel Zelaya soon came to be allied with Latin America's bloc of radical left-wing governments - this being the first case of a post-democratization right-to-left policy switch in the region. The aim of this article is to assess the reasons that could have motivated Zelaya's ideological turn. After a brief discussion of the Honduran political process, we review the literature about the issue of policy switching and proceed to an empirical analysis of the Honduran case. We find that the fragility of the country's energy sector and the alliance with Venezuela in a context of international economic crisis and high oil prices could have triggered a causal mechanism in Honduras similar to the one caused by currency scarcity and international pressure pointed to by the literature as the leading cause for traditional left-to-right switches, which suggests that this case study could serve as a pattern-matching exercise to the general findings of currently accepted switch theory.
\end{abstract}

\section{Keywords}

policy switch, Honduras, right, left, Manuel Zelaya

\section{Introduction}

José Manuel Zelaya Rosales was elected to the Honduran presidency in November 2005 on the electoral ticket of one of the country's most traditional political parties, the Liberal Party of Honduras. A member of the Honduran social and economic elite, Zelaya soon came to be allied with the bloc of radical leftist governments in Latin America and was later forced from office by a civil-military coup instigated by members of his own party, in an alliance with the armed forces and business elite and with the cooperation of the congressional opposition. This could be the first case in Latin America's post-democratization history of a candidate elected on a right-of-center platform switching to left-of-center policies after taking office.

\section{Corresponding author:}

Clayton M. Cunha Filho, IESP-UERJ, Rua da Matriz, 82, Rio de Janeiro, 22260-100, Brazil

Email: clayton.filho@gmail.com 
The opposite phenomenon, in which candidates are elected on a left-of-center platform and later switch to pro-market policies, has been widespread in post-democratization Latin American history. Susan Stokes (2001) was the first to examine this left-to-right switch in a systematic manner, though the phenomenon was initially categorized by Paul Drake (1992) and Kenneth Roberts (1995) as a 'bait-and-switch strategy', and held to be characteristic of a new brand of populism in Latin America. Stokes (2001) studied 44 elections between 1982 and 1995 and identified 16 cases of policy switching out of the 27 leftist politicians elected during this period. ${ }^{1}$ Building upon Stokes's work and expanding her database as well as the variables considered, Daniela Campello (2011, forthcoming) studied 89 elections between 1978 and 2006, identifying 20 cases of policy switching among the 32 leftists elected. Honduras under Zelaya is the first documented instance of a right-to-left policy switch, making it a valuable case study for scholars interested in the policyswitch phenomenon. In this article, we seek to assess this novelty and endeavor to explain the Honduran leftward shift under the presidency of Manuel Zelaya.

We begin with a description of the Honduran political system and Zelaya's political trajectory, from his election in 2005 to his ousting in 2009. We seek to characterize his right-to-left drift and identify indicators that might help to explain its causes. It is not our intention to argue whether Zelaya became the leftist radical that his antagonists portrayed as they forced him from the presidency in a coup. The debate surrounding what it means to be a leftist today, particularly since the fall of the Berlin Wall and the end of the Soviet Union, is ongoing and widely contested, and is beyond the scope of our present study. However, the most important point of contestation and cleavage between left and right in the post-democratization Latin American context is arguably opposition to or support of neoliberal policies and reforms associated with the so-called Washington Consensus (see Williamson, 1990). The policy-switch theory itself arose from studies of the structural adjustment policies adopted or imposed throughout the region in the 1980s and 1990s (see Campello, 2011, forthcoming; Stokes, 2001). Scholars developing and employing the policy-switch theory have generally considered opposition to or support of neoliberal policies as an acceptable proxy for the coding of cases as either having campaigned or governed from the left or the right. We have adopted a similar coding scheme in the Honduran case study.

We first outline how Zelaya drifted from a right-of-center campaign to a left-of-center government, and we proceed to a discussion of the policy-switch literature in the context of existing theoretical developments. We offer an empirical assessment of the Honduran data and then endeavor to explain what theory-based indicators might account for Zelaya's policy switch. It is important to note that this is a single case study and not a broad comparative analysis. But policyswitch theory itself, upon which we build here, is based upon solid empirical comparative studies and statistical testing, and we analyze our data using the best-developed causal model put forth in the academic literature (see Campello, 2011, forthcoming). Campello finds that switches tend to happen in contexts of currency scarcity, tempting presidents elected on a leftist platform to move to the right in order to attract much-needed capital to revive flagging economies. This kind of investment typically comes from two sources: international financial institutions (IFIs) such as the International Monetary Fund (IMF) or the World Bank (entities which impose pro-market conditionalities on loans), and private investors (who look to these IFIs' evaluations regarding governments as signals for investment in countries). As right-of-center politicians already tend to favor pro-market policies and as there are few (if any) sources of capital available for compliance with leftist policies, there would be no reason for such politicians to switch to the left.

We thus treat our case study as a pattern-matching (see Gerring, 2012) test of Campello's theory. We accept its theoretical validity, ask what else would derive from the theory's causal mechanisms, and attempt to match the data from our case with the predictors of the statistical model. Our case 
study finds Zelaya's Honduras to be in close alignment with Campello's empirical predictors for a switch were it not for the fact that the candidate switched in the reverse direction. However, though it was not predicted in Campello's study, the Honduran case would still be theoretically possible within her framework if there were a leftist financier with enough resources and will to influence the country's political course. We find that Venezuelan President Hugo Chavez's active oil diplomacy could well have played the role of this omitted variable.

We then assess the likely causal path explaining Zelaya's switch and consider alternative hypotheses, such as the possibility of prior personal inclinations (of Zelaya, in this case) to lean to the left and the relative increase of Honduran social movement mobilization since the early 2000s. We conclude with general remarks about potential avenues for future research on the policy-switch issue and on the possible future development of the post-coup Honduran political system.

\section{The Honduran political system and Zelaya's trajectory: from establishment candidate to leftist president}

Since the return to democracy in 1982, the Honduran political system has been marked by one of the most institutionalized party systems in Latin America, according to Mark P. Jones (cited in Taylor-Robinson, 2009). It has also been characterized by the nonpolarized hegemony of two political parties situated at the right end of the ideological spectrum, the Liberal Party of Honduras (PLH) and the National Party of Honduras (PNH) (Peetz, 2009). Natalia Ajenjo Fresno (2007: 165) qualifies it as an 'imperfect bipartism, with two traditional parties (the PLH and PNH) occupying the same ideological space despite the existence of greater internal heterogeneity in the case of the PLH, and three small parties situated at the center-left [the Christian Democratic Party of Honduras $(\mathrm{PDCH})$ and the Unity and Innovation Party (PINU)] and left [the Democratic Unification Party (PUD)], legalized since the democratic transition in 1980 (except for PUD, in 1994)' (see also Castellanos, 2006). In a study conducted by the University of Salamanca in which representatives of Latin American parties were asked to locate themselves on a 10-point ideological scale (with 1 being the extreme left and 10 the extreme right), the average score of the PLH was 5.35, with 6.79 for the PNH and 1.00 for the PUD, as shown in Figure 1 (cited Taylor-Robinson, 2009: 484).

The hegemonic parties have rotated in power and have represented many more 'instances of conflict regulation between the different parts of the country's socio-economic elite' than 'organizations of interest aggregation among the population' (Oettler and Peetz, 2010: 86). While the cleavages between liberals and conservatives in Honduras have their origins in the 19th century, they did not represent an explicitly manifest ideological divide, but rather a means employed by the elite to compete for access to state resources (Taylor-Robinson, 2006: 115). As such, electoral disputes between both parties are typically centered more on the personality differences of candidates than on ideological differences or policy proposals.

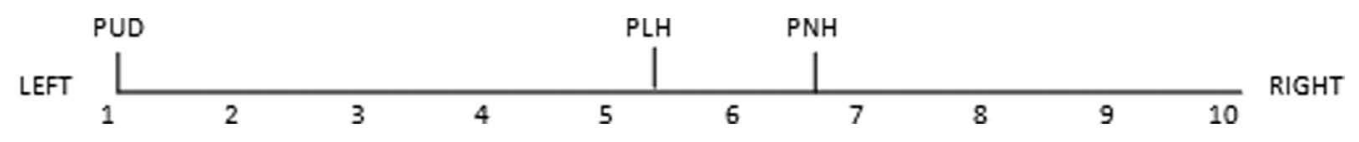

Figure I. The Honduran Party System's Ideological Dispersion for the 2006-10 Legislature Note:We do not include the ideological positions of the PINU and PDCH due to an insufficient number of legislative seats.

Source:Authors' own elaboration of data from Salamanca University's Proyecto Élites Latinoamericanas: Honduras (20062010) cited in Taylor-Robinson (2009). 
The 2005 election was no exception. The polarized contest between Manuel 'Mel' Zelaya (of the PLH) and Porfirio 'Pepe' Lobo (of the PNH) was marked by stark personal accusations between the candidates. ${ }^{2}$ The electoral campaign centered around three main issues: (1) problems of democratic legitimacy (for example, corruption and how to increase citizens' participation); (2) the degree of public intervention in the economy (for example, subsidies, taxation, and incentives for specific sectors); and (3) public security (Ajenjo Fresno, 2007: 173). These issues were not sufficient, however, to produce any significant programmatic polarization between the two main parties. The most prominent issue was public security and the struggle against the maras,${ }^{3}$ the main distinction between the two candidates being Lobo's proposal to reinstate the death penalty and Zelaya's support of life imprisonment preceded by attempts to reintegrate individuals guilty of past crimes into society (Paz Aguilar, 2006). Only when compared directly with Pepe Lobo's more extreme stance on sentencing could Zelaya be described as the centerright candidate in the presidential campaign. Zelaya was elected with 49.9 percent of the popular vote; Pepe Lobo received 46.2 percent of the vote and the candidates of the other three parties garnered slightly in excess of 1.0 percent each (1.02 percent for the PINU, 1.40 percent for the PDCH, and 1.51 percent for the PUD) (see Ajenjo Fresno, 2007: 168). This Honduran bipartism was considered so stable and with so few apparent cleavages between the two parties that it led Joseph Klesner (2006: 35) to remark that 'Honduras's two-party system, the most stable in the region, offers little contrast on policy issues between the parties ... Zelaya had promised to eliminate government corruption while Lobo Sosa took a tougher line on law-and-order issues. Both advocate free trade with the U.S. Hence, Honduran politics will probably change little under Zelaya's presidency.'

As a candidate in the 2005 election, Manuel Zelaya ran his campaign (and subsequently began governing) as a member of the business and social elite, bringing his network of contacts with him. An agricultural businessman from a traditional landowning family, ${ }^{4}$ he was also a former board member of the powerful Honduran Council of Private Enterprise (COHEP) and former president of the National Association of Wood Transformation Enterprises (ANETRAMA) (Ajenjo Fresno, 2007; Ortiz de Zarate, 2011; Peetz, 2009; Rusiñol, 2009). At the beginning of his administration, he apportioned cabinet posts among the different factions of the PLH, filling his government with traditional family names from Honduran politics and members of the economic elite and signaling an apparent intention to maintain the status quo ante. The only significant change was the introduction of gender parity in the distribution of cabinet posts (Ajenjo Fresno, 2007: 175).

Despite Zelaya claiming credit for the Ley de Participación Ciudadana (Citizen's Participation Law or CPL), enacted just a few hours before his inauguration, the implementation of this law (intended to open more direct channels for political participation, with the creation of the National Forum for Citizen Participation, the Municipal and Departmental Development Councils, and the Community Boards of Citizen Participation) was still dependent on the traditional political structure, packed with leaders from the PLH or people close to Zelaya, thus hindering its potential for transformation of the Honduran 'particracy' (that is, the strong and impervious domination of its political system by the two dominant parties). The law itself was the continuation of institutional channels of civil society participation which had been developing since the end of the 1990s under the framework of the Heavily Indebted Poor Countries Poverty Reduction Strategy (HIPC-PRS). Financed by IFIs such as the World Bank, the HIPC-PRS required the consultation and participation of civil society in order for countries to accede to debt reduction (see Cuesta, 2007; Dewachter and Molenaers, 2011; Komives, 2011). In the Honduran case, this led to the creation of the Consultative Council (Consejo Consultivo), composed of members of the government and civil society in equal proportions, which played an important role in the formation of the CPL and its participatory institutions. 
Zelaya's first year in office (that is, 2006) was to a great extent a continuation of the administration and policies of the former president (Ricardo Maduro of the PNH, who held office during 2001-05), with slight changes in rhetoric encouraging more citizen participation and an increase in the number of policies and programs impacting the rural poor, improving environmental protection, and furthering municipal reform. Zelaya's foreign policy during his first year in office was also one of continuity. It was oriented toward the USA, supporting the Central American Free Trade Agreement (CAFTA-DR) and aiming to avoid the deportation of illegal Honduran immigrants, and toward international money-lending institutions, looking for debt relief (see Ajenjo Fresno, 2007). ${ }^{5}$ In hindsight, the most important policy of this first year was entering into a process to solicit international bids for the supply of oil and derivatives. The final results of the competitive bidding process were announced by the president in November 2006, with the choice of ConocoPhillips for the provision of gasoline and diesel and of Gas del Caribe for liquefied petroleum gas.

From the government's start in January 2006, Honduras was already facing an energy crisis that forced the president to declare a state of emergency for the sector just four days after taking office and prompted his personal intervention to bail out the state-owned Empresa Nacional de Energía Eléctrica (ENEE) in February 2007. Because two-thirds of the country's electricity generation comes from oil-burning processes and the country is dependent upon imported oil and does not own any refineries, this renders the Honduran energy sector extremely fragile and susceptible to fluctuations in global oil prices (Pirker and Núñez, 2010). The ENEE, the generator and supplier of electricity (and Honduras's largest company), was in a dire financial situation at the time (nearly bankrupt and with yearly losses of about US\$160 million) and incapable of supplying the country's full energy demand (Ortiz de Zarate, 2011; Pirker and Núñez, 2010). Zelaya's decree created an emergency fund of US\$15.8 million in order to pay for fuel subsidies (an action which allowed for a price freeze until the fuel-bidding results could bring about improvements in the economy) and took out an energy insurance policy to cushion fluctuations in international oil prices (Murillo Parrales, 2006).

The competitive bidding process itself was the continuation of measures taken in 2005 by Zelaya's predecessor, President Ricardo Maduro, and came from the recommendations of an independent consultant hired by the Commission of Notables in order to evaluate and restructure the country's energy sector. ${ }^{6}$ The bidding process was intended as a measure to lower the sector's costs, but it faced strong opposition and a boycott imposed by the transnationals Esso, Texaco, and Shell - companies that had dominated the sector in Honduras for decades. The US Ambassador to Honduras, Charles Ford, roundly criticized the measure, calling it a 'sudden change of the rules of the game' for foreign investments (see Murillo Parrales, 2006; Pirker and Núñez, 2010: 118). In the midst of the political tension caused by the bidding process, Zelaya accused the three transnationals of blackmail and 'energy terrorism.' Zelaya also ordered the seizure of all ports and storage tanks controlled by the companies, transferring management of the facilities to ConocoPhilips as he signed the new contracts into law in January 2007. This power play by Zelaya was short-lived, however, as he ended up rescinding the confiscatory measures after the US Embassy issued an official note of protest.

The conflict over the fuel-provision rule changes is a particularly important issue for the country (fuel comprises approximately one-fifth of total Honduran imports and all of the country's fuel is imported). The episode also facilitated a rapprochement between Honduras and Venezuela which was to prove crucial for the country's left switch (see Meza, 2006). While some observers have questioned the sincerity of Zelaya's turn to the left (for example, Peetz, 2009), the prevailing view is that he indeed drifted from a right-of-center political campaign in 2005 to a left-of-center 
program that radicalized somewhat over time (Cálix, 2010; Moreno, 2009; Pirker and Núñez, 2010; Rusiñol, 2009) - a switch that was consolidated with the country's entry into the Bolivarian Alliance for the Peoples of Our America agreement (ALBA) in 2008.

The symbolic start of the Zelaya administration's switch is its participation in the 28th anniversary of the Sandinista Revolution in Nicaragua in July 2007 (Llanos and Marsteintredet, 2010b: 180), an event which generated fierce criticism from the Honduran right and from the US Embassy (Moreno, 2007). In December of that year, the shape and direction of the government began to become more apparent when Zelaya announced that Honduras would join the Petrocaribe agreement, a Venezuelan regional energy initiative that provides oil and derivatives at favored payment conditions.

The domestic reaction to this announcement was mixed. Business associations and the conservative press recognized that the terms of the Petrocaribe alliance were extremely favorable to Honduran interests in economic terms, as they allowed an economically poor and fuel-dependent country to access oil derivatives under very flexible financing conditions, including an option to pay its oil purchases off, in part, by bartering agricultural goods for fuel. ${ }^{7}$ At the same time, they expressed concerns that the agreement might signify a shift from strictly private-sector networks to more politically based relationships more in alignment with Chávez's socialist-leaning policies. The President of the Honduran Congress, Roberto Micheletti (from the PLH), who had already declared himself a candidate for Zelaya's succession, demanded increased transparency and certain assurances in the agreement, after which a congressional special committee authorized the president to sign it on 24 January 2008. On 13 March 2008, the Congress voted and ratified Honduras's adherence to the agreement, with 'yes' votes coming from the PLH, the PINU and the PUD, 'no' votes from the PDCH, and the PNH abstaining.

The first Venezuelan fuel shipment reached Honduran ports at the beginning of June 2008. On 22 July 2008, Zelaya announced his decision to move the country's new international alliance one step further and join ALBA, a bloc of countries led by Venezuela that had come together in 2004 as an alternative to US hegemony in the region and what it considered the failures of neoliberalism and free-market integration. ALBA was generally considered to be comprised of Latin America's radical left-wing countries ${ }^{8}$ and included, at the time, Venezuela, Cuba, Bolivia, Nicaragua, and Dominica as signatories. ${ }^{9}$ Unlike Petrocaribe, the decision to join ALBA met with strong criticism from Honduras's elites and polarized the country. Only certain factions from the PLH, alongside the PUD, some trade unions, and peasant organizations such as the Coordinator Council of Honduran Peasant Organizations (COCOCH), favored entry into the ALBA agreement, while it was opposed by the PNH, mainstream Honduran newspapers, and business associations (patronales) such as the COHEP, ${ }^{10}$ the Chamber of Commerce and Industries of Tegucigalpa (CCIT), the National Industrial Association of Honduras (ANDI), and the Honduran Maquila Association (AHM).

On 25 August 2008, Zelaya signed the ALBA agreement during a ceremony attended by the presidents of Venezuela, Nicaragua and Bolivia and the vice-president of Cuba, at which Zelaya announced for the first time that his government was left of center. Despite the opposition it generated, entry to ALBA was approved by the Honduran Congress on 9 October 2008 with the support of the PLH, PINU, PDCH and PUD and the abstention of the PNH's representatives. There was significant support on the part of Micheletti, who essentially ceded his leadership position in Congress in exchange for Zelaya's support in the upcoming PLH presidential primaries. ALBA continued to polarize the political environment, with the media becoming increasingly critical of the alleged Chavista influence in Honduran politics (Llanos and Marsteintredet, 2010b: 181). 
At the end of December 2008, after one month of failed negotiations with the business community, the government decided to increase (by presidential decree) the minimum wage by about 60 percent. In response, Honduran business associations threatened to fire one out of every three employees and challenged the constitutionality of the increase in the Supreme Court (Cordero, 2009: 19). The policy added fuel to the country's social tensions until the court decided to uphold the increase in March 2009. But it was an earlier decision by Zelaya on 22 November 2008 calling for a referendum for the formation of a Constituent Assembly that arguably led directly to the coming coup d'état.

From the start, Manuel Zelaya had adopted 'Gobierno del Poder Ciudadano' (Citizen's Power Government) as his administration's motto, but apart from the CPL, enacted just before he was sworn into office, not much was actually done to empower the citizenship. The legislation did not live up to its promise, as the new councils created were packed with party bosses who maintained the patronage networks characteristic of Honduran politics. But in November 2008, Zelaya proposed the formation of a Constituent Assembly whose purported goal was to transform the country's participatory structures and institutionalize mechanisms of direct democracy.

By this point, Zelaya had entered the lame-duck stage of his presidency (Moreno, 2009). Even leaving aside the growing ideological divide between Zelaya and the rest of the PLH, the president was starting to lose the support of his party as his leverage through the traditional patronage links diminished. The PLH had already named its candidate for Zelaya's succession in November and previously enacted electoral reforms had taken away the outgoing president's power to influence the party's list of congressional candidates (Ajenjo Fresno, 2007; Llanos and Marsteintredet, 2010b; Meza, 2006; Taylor-Robinson, 2006). To make matters worse for Zelaya, Roberto Micheletti (whom he had personally sponsored and whose legislative support had been critical in Zelaya's leftward switch) lost the primaries to Vice-President Elvin Santos ${ }^{11}$ and, with that, any incentive to cooperate with the president. Micheletti, in fact, started to use his institutional powers to block Zelaya's agenda from that point forward.

Zelaya issued a statement on 23 March 2009 calling for a 'broad popular consultation' in June over whether to hold a national referendum on the formation of a Constituent Assembly. The president had initially intended to send a bill to Congress ordering the binding referendum to be held alongside the November 2009 general elections, but as he could no longer count on a secure legislative majority, he opted for this unofficial (and nonbinding) referendum in an effort to apply pressure on Congress to enact the official referendum law (Llanos and Marsteintredet, 2010b: 182).

An institutional crisis emerged around the issue of state powers as the attorney general overruled the decree. Zelaya then tried to reframe the referendum with another decree on 26 May 2009 , calling it a national opinion poll to be conducted by the National Statistics Institute (INE) over the desirability of the 'Fourth Urn.' ${ }^{2}$ As Llanos and Marsteintredet (2010b: 183) explain, by removing the name 'popular consultation' and calling it an 'opinion poll,' the government sought to avoid a constitutional crisis by including the measure inside the legal framework of the CPL (the Honduran Constitution establishes the Congress as the only legitimate body for approving such national referenda). The PNH and a majority of the PLH criticized Zelaya's referendum proposition and the Congress passed a preventive law on 24 June, just four days before the opinion poll was scheduled, stating that no referendum could be conducted within 180 days (either before or after) of a regularly scheduled election.

When the Commander of the Armed Forces, General Vásquez Velásquez, refused to obey Zelaya's decision to order the military to provide logistic support for the polls, the president dismissed him from the position, triggering the joint resignations of the Defense Minister, Edmundo Orellana, and the commanders of the three armed forces. The crisis further escalated when the 
Supreme Court ordered General Vásquez Velásquez to be reinstated (a power it constitutionally lacked) and Zelaya refused such an order, claiming its illegality. At dawn on 28 June 2009, President Zelaya was kidnapped by the military from his house, still in his pajamas, and sent abroad to Costa Rica, with Roberto Micheletti being sworn in by Congress as president in his place. The coup was the end of the Zelaya government, but not of the country's political crisis, which lasted until the end of the year - and, in some senses, even beyond it. The crisis involved the expulsion of Honduras from the Organization of American States (OAS); failed attempts at mediation for Zelaya's return to the presidency; his clandestine return to the country and refuge inside the Brazilian Embassy; the subsequent siege of that embassy by Honduran troops; the activation of a previously nonexistent broad-based and radicalized leftist movement of resistance; and a joint Colombian and Venezuelan mediation agreement which permitted Zelaya to return to the country with restored political rights and without judicial prosecution almost two years after his ousting. This agreement permitted Honduras's reinstatement to the OAS. ${ }^{13}$

Honduras under Zelaya experienced a phenomenon quite common in Latin American politics and described in the academic literature as a policy switch: when a president is elected on one platform, but later switches it for an opposing one. Table 1 traces the main political events along Zelaya's leftward path. ${ }^{14}$ What makes this case of particular interest to observers of the policyswitch phenomenon is that all policy switches previously studied in the region occurred from left to right, that is, with candidates running and being elected on a leftist platform and later moving to a more right-of-center program. Zelaya appears to have done just the opposite. Our primary research question is to determine why this was the case by examining possible theoretical explanations.

\section{The policy-switch theory: looking for answers}

According to Hanna Pitkin (1972), one of the normative characteristics of elections (assuming a maximum correlation between representatives and represented) is that each party and candidate should reveal their intentions before elections are held, presenting a platform of public policies they will adopt should they be elected. Since at least the second half of the 18th century candidates have used campaign manifestos, speeches, debates, and other media as vehicles for presenting and disseminating their intentions. Consequently, candidates generate expectations in the electorate about how the government would act when confronted with certain issues and scenarios. These platforms are typically framed in contrast to their opponents' proposals across the full ideological spectrum so that citizens can select their representatives according to the political platform that best fits their preferences.

This theoretical view, however, necessarily implies deviations by the elected representatives, since it is impossible to know the opinions of the represented on a full range of political, economic, and social issues. In contemporary Latin America, there are numerous (and notorious) examples of presidents elected on a pledged platform only to switch and adopt opposing policies after being sworn into office.

Studying populism in Latin America, Paul Drake (1992) described what he called 'bait-andswitch' strategies, in which candidates engage in a redistributive discourse in order to attract the support of the poor, only later to apply neoliberal structural adjustment policies. It is possible that these 'bait-and-switchers,' as Drake called them, would actually prefer to implement their favored redistributive policies, but were forced by constraints deriving from market imperatives to implement orthodox policies. Kenneth Roberts (1995) proposed the bait-and-switch argument as one of the core characteristics of a new kind of Latin American populism (broad-based and supported by 


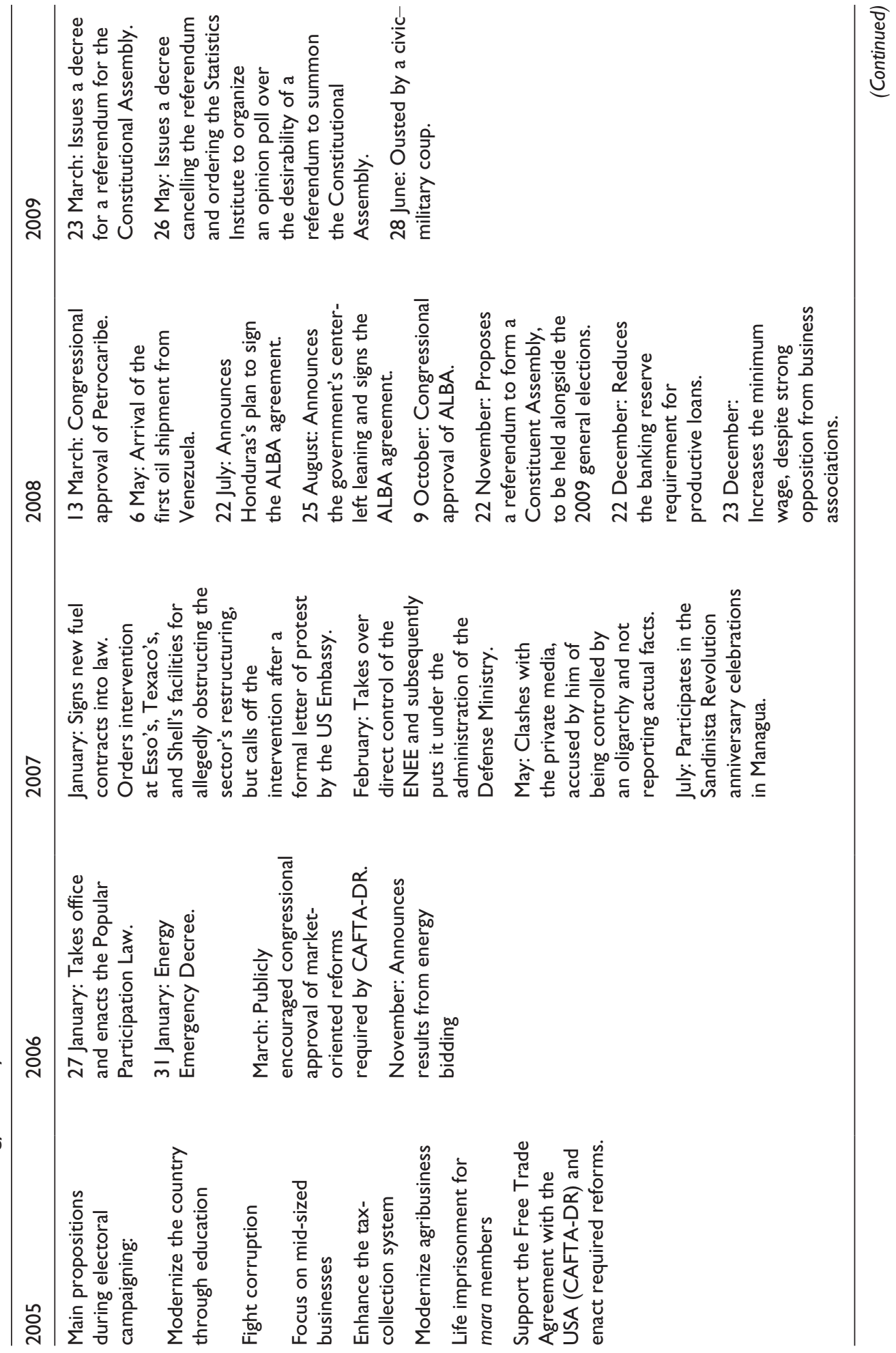




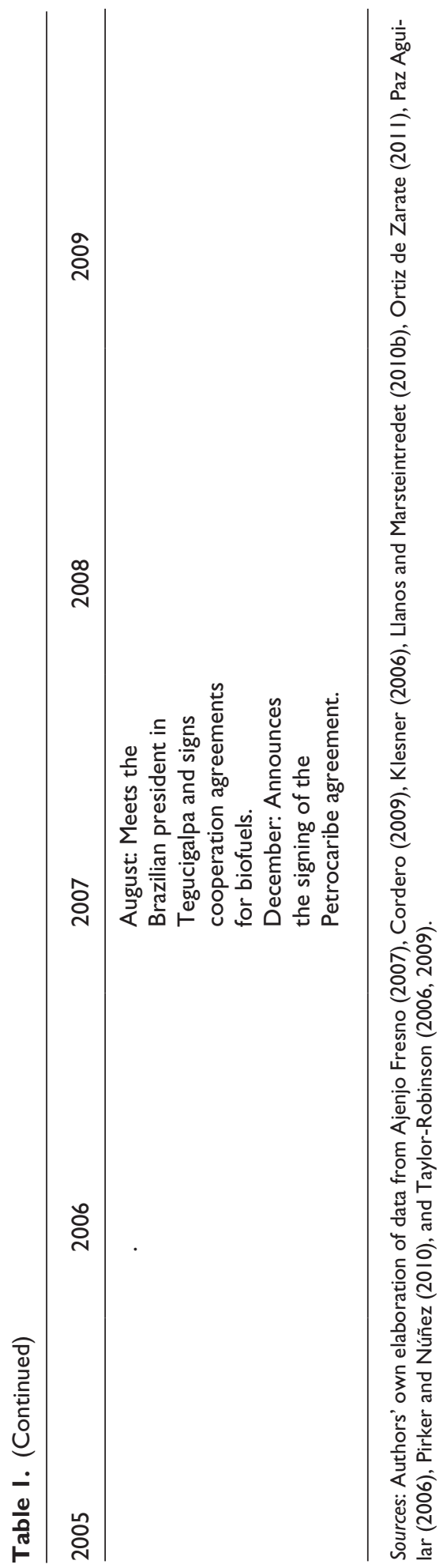


the lower classes, but implementing market-driven policies) of which presidents Alberto Fujimori of Peru (1990-2000) and Carlos Menem of Argentina (1989-99) are exemplars.

But the first scholar to undertake an analysis of the policy-switch phenomenon in and of itself (that is, not simply examining it as one of many characteristics of populism) was Susan Stokes (2001), who studied 44 Latin American elections between 1982 and 1995. ${ }^{15}$ Analyzing the implementation of neoliberal reforms and their consequences for the region, Stokes employs arguments of political representation to develop a theory explaining policy switching in the region. She posits three kinds of political action on the part of representatives: (1) representatives whose beliefs coincide with the median voter (these politicians campaign by revealing their true intentions and act according to them when they are elected); (2) representatives whose beliefs do not coincide with the median voter, but who think that their own beliefs would not prevail over those of the median voter to the point of causing a shift in attitudes in the electorate; and (3) representatives who conceal their true intentions during the campaign and, once elected, take an opposite path to the one suggested, implementing policies they believe are better than the ones preferred by the electorate.

For Stokes, Latin American politicians act strategically by promising attractive policies for the electors. However, once elected, they adopt conservative policies with the aim of maximizing economic performance and the likelihood of getting reelected. Stokes (2001: 95) compares the effect of GDP growth rates on the incumbent's share of the vote, and weighs this effect among switchers and non-switchers. The proposed theoretical model of representative politicians predicts policy switches when politicians believe voters are uncertain. The model also expects policy-switching incumbents' share of the vote to be more sensitive to GDP change at the end of their term than that of non-policy-switching incumbents. Stokes explores different models with a variety of specifications to test the hypothesis that term limits increase the probability of a policy switch. The model she adopts includes two dummy variables: one in which the president is free to run for immediate reelection and another in which the president can never run again. The independent variable measures the proportion of parliamentary seats controlled by the president's party.

Stokes found that the policy switches in Latin America always occur from left to right. Her results show that a majority of presidents ( 27 out of 44 , or 61.4 percent) have been elected with left-of-center political platforms and alliances, promising popular and non-neoliberal policies. Out of the 27 left-wing candidates elected from her sample, 16 (59.3 percent) switched to pro-market policies once in office and acted contrary to the platform on which they were elected, strengthening so-called structural reforms, making deals with international financial institutions, and deepening macroeconomic adjustment in order to maximize the country's economic performance and boost their reelection chances.

Daniela Campello (2011, forthcoming) builds on Stokes's findings and expands the sample from 44 to 89 cases of Latin American elections during 1978-2006. ${ }^{16}$ Following Stokes's scheme (2001), Campello (forthcoming) uses privatization, deregulation, liberalization of trade and finance, central bank autonomy, and the adoption of orthodox fiscal and monetary policies as proxies for right-of-center policies (both during the campaign and while in office) and increased social expenditure, trade restrictions, income redistribution, industrial policies, and limitations on the payment of the external debt as proxies for leftist policies. In a content analysis of media coverage of the victorious campaigns and the incumbents' first year in office, Campello finds a total of 20 cases of policy switching, all of them among presidents elected with a leftist platform $(N=32)$, or about 60 percent of all victorious leftist candidates from the dataset.

Campello challenges Stokes's failure to address the unidirectional nature of the policy switch. There is no a priori reason why a candidate who has campaigned on the left would not embark upon his promised platform once elected, unless one assumes beforehand that right-of-center policies 
are somehow normative in nature. Indeed, as Campello's data show (2011, forthcoming), some candidates did adhere to a left-of-center platform, thus asking for a causal explanation of why some, even if the majority, did not.

Campello statistically tests a number of hypotheses to look at the potential causal role of economic and political variables in policy switches. Her research design also tests the impact of currency crises and booms on the probability that a policy switch will occur. She examines a probit model in which the dependent variable is 'Switch' and the explanatory variables capture currency fluctuations in the months immediately before and after a presidential inauguration, as well as political conditions that may help explain a president's probability of switching.

Campello's explanatory variables include measures for (1) dollar scarcity or abundance in the economy, (2) executive power, (3) the incumbent party's control of congress, (4) electoral volatility, (5) party institutionalization, and (6) inflation. Campello finds that the main predictor for a policy switch is economic, with the occurrence of a currency crisis alone being able to account for 77 percent of the switches. ${ }^{17}$ Among the political factors, the most significant variable is the strength of the executive's constitutional powers, with the influence of legislative control being positive, but at low levels of significance. The capability of the president to enact his or her switch once this decision has been made is crucial, according to Campello, because a lame-duck president could choose to switch, but might not have the capacity to do so.

Campello also finds that a scarcity of international reserves leaves a country vulnerable to pressure from international investors, who demand the adoption of pro-market policies in return for the capital they invest. This would explain the unidirectionality of the phenomenon: right-of-center incumbents would already be pursuing the kind of policies demanded by the markets. Even when caught in a currency crisis in which such incumbents desperately need to attract capital, there would be no incentive to switch to the left. When leftist candidates come to power on a less marketdriven platform, but find themselves faced by a currency crisis, they may feel pressured to abandon their campaign promises and switch to a pro-market approach in order to attract the capital needed to revive their flagging economies.

This leaves us with the puzzle of explaining what caused the Honduran government under Zelaya to be the first case of a reverse policy switch, with a leader elected on a right-of-center platform moving to the left. The Honduran case was one of the 89 cases considered in Campello's dataset, but she did not code it as a switch, instead grouping it with those cases of presidents elected on a pro-market platform that adhered to that platform. This is likely due to methodological issues related to Campello's large- $N$ study, which required her to focus only on a president's first year in office. Campello's determination (and subsequent coding) of whether a policy shift occurred, in other words, uses data captured from the first year only of a multiyear term, omitting the possibility that a president may shift later in the term. Zelaya's switch did not take place until sometime between 2007 and 2008 (more than a year into his term), and therefore was not captured in Campello's data. Apart from the large- $N$ nature of her study, the only explanation Campello offers for focusing solely on the first year in office is to keep to conditions as close as possible to those of the campaign. Her rationale for this is that eventually a president might switch policies due to changed circumstances and conditions, characterizing a somewhat different phenomenon than the classic switch. But the structural conditions and key events from Zelaya's presidency developed out of conditions already present at the time of his election, making this a phenomenon of the same class as the others. Because this is a single case study, we were able to analyze the government's actions from the beginning until the coup and notice the switch to the left when it did occur. Guided by recent and ongoing developments in policy-switch theory, we will attempt to offer some 
possible causal explanations for Zelaya's right-to-left policy switch, while examining the Honduran data in more detail.

\section{Solving the puzzle: the Zelaya case as a pattern-matching exercise}

The Honduran case under Zelaya fits remarkably well with the main indicators of Campello's model - apart from the fact that it was a right-to-left (rather than the more common left-to-right) shift along the ideological spectrum. As stipulated in Campello's model, the Honduran presidency is moderately strong with regard to its proactive constitutional powers (see Payne et al., 2007: 98) and Zelaya had majority support from the legislature during the period when the switch occurred - presenting the necessary political conditions for a switch. Moreover, Honduras is a very poor country with a nondiversified economic structure that is highly dependent on the export of agricultural commodities and a few maquilas ${ }^{18}$ (Cordero, 2009), which, coupled with its fixed exchangerate system, makes it vulnerable to external shocks and currency crises. Indeed, the country was experiencing a steep deterioration in its current account balance and declining international reserves in relation to its import requirements (see Table 2). Following Campello's theoretical approach, these conditions together are strong indicators for the likelihood of a right-to-left policy switch, but we argue that the causal mechanism she identifies could also be responsible for a reverse switch in the Honduran scenario.

The reason for the unidirectionality in Campello's findings, according to her, is both the promarket conditionalities imposed by the IFIs (such as the World Bank and the IMF) and the promarket signals required by international investors in order to provide capital to governments facing currency crises. As there are no traditional international sources of capital pressing for left-ofcenter policies in exchange for resources, no candidate elected on a right-of-center platform would be tempted to switch to the left. But there is nothing, in theory, that would prevent a reverse switch from occurring, should such resources be available. We propose to examine the Honduras case under Zelaya as a pattern-matching exercise (see Gerring, 2012) to Campello's theory. That is to say, we accept its theoretical validity, and pose the following question: What alternative outcomes might derive from its causal mechanisms? As Honduras presents the theoretical preconditions for a switch, all that remains is a left-leaning source of international capital.

The Venezuelan cooperation programs fit the profile of such a leftist source of international financing. These programs allow countries from the Caribbean to fulfill their oil and derivatives needs under friendly financial conditions, while explicitly creating funds for financing social and economic development programs. Petrocaribe has its origins in June 2005 as an agreement between the Venezuelan state company PDVSA and 15 countries from the Caribbean basin. The rules created by Petrocaribe stipulate that in importing oil and derivatives from the PDVSA, members of the agreement are able to pay half of the bill immediately and the remainder through a 25 -year financing mechanism at interest rates not to exceed 2 percent. Governments are also required to invest the saved resources in social and infrastructure projects.

Honduras signed the Petrocaribe agreement in December 2007, but the Zelaya government had publicly accepted Chavez's oil offerings at least since May 2006 and, although it was not selected, the PDVSA had participated in the international bidding for the provision of fuels organized by Zelaya in that year. A few months after the entry of Honduras as a full member of Petrocaribe, Chavez announced even better conditions for Petrocaribe members: in the event that oil prices exceeded US\$100 per barrel (as was the case at the time), the now 18 members of the agreement could pay 40 percent of the bill 90 days after they received the oil and the remainder could be 


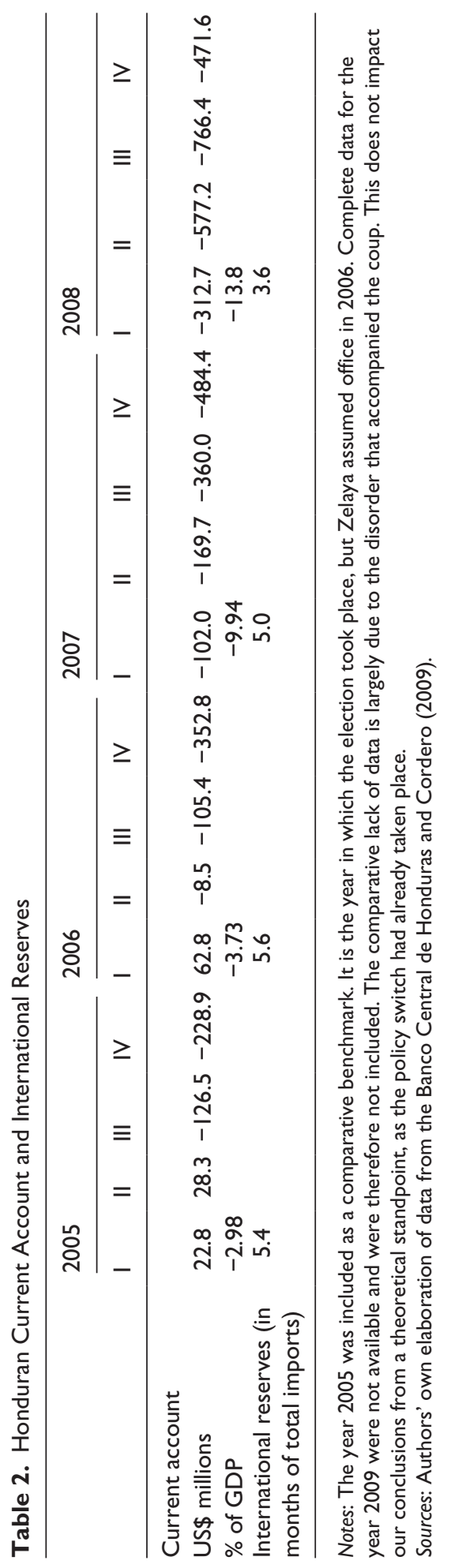


financed at a 1 percent annual interest rate over a 25 -year period; should prices rise higher than US\$150 a barrel, the first payment would be reduced to only 30 percent of the total price. With entry to ALBA, a country gained access to even greater benefits. The official document for Honduras's accession to ALBA states that the country would benefit from the following cooperation programs and transfers.

1. A US\$30 million loan from the Economic and Social Development Bank of Venezuela (BANDES) to be administered by the National Bank of Agricultural Development of Honduras.

2. Venezuela would purchase a package of US\$100 million in Honduran national bonds. These funds should then be invested in credits for the informal sector of the economy and housing programs.

3. Studies for oil prospecting and production on the Honduran Caribbean coast would be conducted.

4. Approval of Honduran projects for ALBA's Fund for Food Production (US\$2 million).

5. Technical assistance would be provided for television production and other cultural initiatives.

6. Health-care cooperation would be established, with Cuban professionals offering services in Honduras.

7. A Cuban scholarship program for studies in medicine, the humanities, and sciences would be established.

8. Cuban literacy programs would be undertaken in 206 Honduran municipalities.

9. In coordination with Cuban agencies, cooperation would be established for the substitution of 4 million incandescent light bulbs by energy-efficient ones.

10. Generic medicines would be provided at cheaper prices by the Cuban pharmaceutical industry.

Zelaya's flirtation with leftist politics is strongly associated with his proximity to Venezuelan President Hugo Chávez; Honduras's entry to ALBA is commonly considered as the consolidation of Zelaya's switch. The alliance with Venezuela could well have been, in this case, the international source of resources needed for a reverse switch. An energy crisis was the first major challenge faced by the Zelaya presidency and it resulted in the breakup of a decades' long oligopoly held by Esso, Texaco, and Shell over the sector, putting the president at odds with the US Embassy. The expropriation threat against the transnationals was not carried through, but the execution of the competitive bidding process alone had already damaged Honduran attractiveness to foreign capital investment as it was portrayed as a breaking of contracts (Pirker and Núñez, 2010: 118). The energy crisis also placed the country closer to Venezuela, as Chávez was already very active using the windfall from high oil prices to fund his diplomatic efforts and attract allies to his projects, most notably in Latin America and the Caribbean (see Pérez Flores and Kfuri, 2011).

Honduras's dependency on imported oil made Venezuela's offer of cheap fuel a very attractive opportunity. Honduran fuel imports represent around 20 percent of the country's total imports, peaking at 23.23 percent in 2008, when oil prices during Zelaya's presidency reached their maximum of an annual average of US\$94.45 a barrel (see Table 3). This is the same year that, influenced significantly by the pressure of oil imports, the Honduran current account balance reached its highest deficit, plummeting to -13.8 percent of GDP (see Figure 2). International reserves represented a mere 3.6 months' worth of imports when Honduras joined the Petrocaribe and ALBA initiatives. 
Table 3. Annual Oil Prices and Fuel Imports in Honduras

\begin{tabular}{lllll}
\hline & 2005 & 2006 & 2007 & 2008 \\
\hline Oil prices (US\$) & 50.64 & 61.08 & 69.08 & 94.45 \\
Total fuel imports (thousands of US\$) & 906,100 & $1,127,683$ & $1,299,126$ & $1,909,655$ \\
Fuel imports as a \% of total imports & 20.47 & 21.25 & 19.88 & 23.23 \\
\hline
\end{tabular}

Notes: The year 2005 was included as a comparative benchmark. It is the year in which the election took place, but Zelaya assumed office in 2006. Complete data for the year 2009 were not available and were therefore not included. The comparative lack of data is largely due to the disorder that accompanied the coup. This does not impact our conclusions from a theoretical standpoint, as the policy switch had already taken place.

Sources: Authors' own elaboration of data from OPEC and the Instituto Nacional de Estadísticas de Honduras.

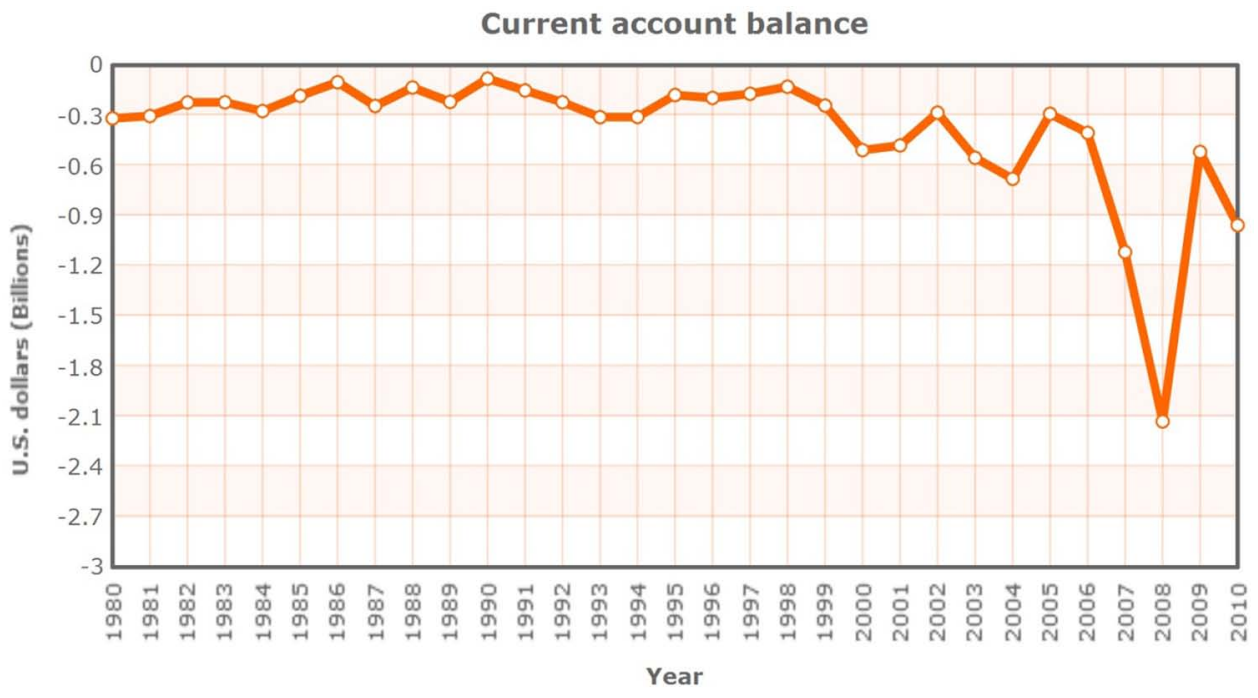

Figure 2. The Honduran Current Account Balance (1980-2010) Source: Index Mundi (2012).

Another factor when considering Venezuela as a potential explanatory variable for Zelaya's leftward shift is that the switch took place when the international financial crisis began to hit emerging markets the hardest (see Dooley and Hutchison, 2009). This means that traditional capital markets that could have been tapped were harder to access at the time; even the IFIs, such as the World Bank and the IMF, were temporarily constrained in their lending capacities. Given such an environment, the resources offered by Venezuela must have looked all the more appealing. Zelaya himself alluded to that fact when, as he signed the country up to ALBA, he declared that it was 'an answer to the shortage of resources.' Private-sector funding was scarce, and when confronted with a choice between a US\$10 million loan from the World Bank or US\$130 million from the Venezuelan government, it was not a difficult decision to make (Altmann Borbón, 2009: 141).

\section{Final remarks}

Of course, we must be cautious not to take Zelaya's words at face value too quickly. It may be possible that something else led to Zelaya's leftward shift, but the concurrence of all the elements 
present in Campello's switch theory (a strong president with a supportive legislature during a currency crisis when there is an external agent offering needed resources) makes it very likely that the Venezuelan offer is indeed the causal mechanism.

An alternative explanation is that it was a rational political calculation on the part of Zelaya to occupy a space (that is, the political left) that was unoccupied up to that moment in Honduras. But the factional and patronage-based nature of the PLH and its leadership structure makes it a dubious strategy to develop one's political career strictly through one's ideological affirmation and association. ${ }^{19}$ Before joining Petrocaribe or ALBA, Zelaya had already confronted problems with rival leaders of the PLH and saw some of his initiatives blocked in Congress by his own party. However, the rejected initiatives were not ideologically divisive and did not cause any lasting harm to the relations between the president and his party. The Micheletti-led PLH granted Zelaya its general support in the legislature until the end of 2008 and was indeed instrumental in helping to forge a number of the president's new (and controversial) foreign alliances.

Zelaya does show some evidence of personal inclinations toward left-of-center political preferences in his pre-presidential political career, despite his socioeconomic origins. ${ }^{20}$ Although associated with the PLH since 1970, Zelaya began a more active participation within the party in 1980 in the Movimiento Liberal Rodista, the PLH's then dominant faction (also considered to be one of its most conservative), which was closely associated with the 1982-86 presidency of Roberto Suárez Córdoba. Zelaya switched allegiance in 1983 to the Movimiento Azconista, which had broken with Córdoba for not supporting the candidacy of José Simón Azcona Hoyo (who ended up winning the presidency in 1985). This is also when Zelaya became a member of parliament for the first time. In 1993, however, Zelaya switched factions again and joined ranks with Carlos Roberto Reina, the leader of a more progressive faction inside the PLH (and the president of Honduras from 1994 to 1998).

It was at this point that Zelaya was invited to run the government agency Fondo Hondureño de Inversión Social (Honduran Fund for Social Investment or FHIS), where he executed the government's social policies and voiced his public criticism of IMF loan conditionalities and of the market-adjustment policies promoted by President Reina at the time. His tenure as head of the FHIS during the Reina administration was considered very successful and he was confirmed again in the post by the next Honduran president, the more conservative Carlos Roberto Flores Facussé (who held office during 1998-2002 and was also from the PLH). After the devastation brought about by hurricane Mitch, Zelaya was appointed as adviser to the Special Cabinet for National Reconstruction. This trajectory shows Zelaya moving from the PLH's most conservative faction to a more progressive one, in which he raised his national profile as the head of the FHIS while promoting and implementing more socially minded initiatives and criticizing the market-adjustment policies being enacted at the time. In spite of these progressive credentials, he still ran for the presidency in 2005 on a conservative platform (Ajenjo Fresno, 2007; Castellanos, 2006; Klesner, 2006; Meza, 2006; Ortiz de Zarate, 2011; Paz Aguilar, 2006; Pirker and Núñez, 2010; Taylor-Robinson, 2006) and switched to more progressive policies after being elected (Cordero, 2009; Grandin, 2010; Moreno, 2007, 2009; Ortiz de Zarate, 2011; Pirker and Núñez, 2010; Rusiñol, 2009). From a theoretical perspective, what is relevant is the switch itself - not whether someone changes course due to personal convictions or pressures from outside forces.

Honduras had, in fact, been experiencing a gradual crescendo of social movement mobilization since at least 2001-02 (Pirker and Núñez, 2010). The rise in social mobilization may have appealed to a political leader trying to associate himself with the left, though this increase was still comparatively quite small. Unlike most of its neighbors in Central America, who faced strong left-wing guerrilla activities in the 1970s and 1980s, Honduras was precisely the country chosen as the base for US-backed counterinsurgency movements, such as the Nicaraguan Contras, which used its 
territory as a haven from whence to launch their actions. As Dewachter and Molenaers (2011: 115) outline, Honduras had experienced the development of strong labor and peasant movements in the 1950 s and had a relatively strong civil society which was severely repressed by the military dictatorships beginning in 1963. Civil society was thus considerably weakened by the time of the democratic transition in 1982 and was dealt a 'mortal blow by the launch of the [market] reforms' in the 1990s (Cuesta, 2007: 337).

A new generation of civil society actors, including nongovernmental organizations (NGOs) and human rights and women's groups, led a wave of mobilization in Honduras in the 2000s. Their efforts started to gain momentum after the devastation of hurricane Mitch and the subsequent reconstruction in 1998, and these groups were often linked to the IFI-financed PRS process and its incentives for civil society participation (Cuesta, 2007; Dewachter and Molenaers, 2011). While the PRS process opened new avenues for mobilization and strengthened participation, the participatory options offered to civil society actors were more consultative and informative than possessing any real power-sharing agenda (Dewachter and Molenaers, 2011; Komives, 2011). However strengthened they may have been, Honduran social movements and civil society remained diffuse and relatively weak when compared with many other Latin American countries, lacking the capacity to mount any legitimate challenge to the status quo (Castellanos, 2006). ${ }^{21}$

Nevertheless, this relative social movement buildup contributed to a change in the opportunity structure (see Tarrow, 1994) that enabled Zelaya's switch, but it must be remembered that the president's popular approval rates were low (although rising in the last months prior to the coup); the main social movement leaders widely distrusted Zelaya and did not lend him any strong grassroots support until after he was forced from office. It seems more likely that economic necessities concurrent with the opportunities available at the time ignited the policy-switch process. The president of a very poor country, highly dependent on imported oil, takes office when his country is facing both an energy crisis and a deteriorating current account balance. Confronting the country's energy problems, Zelaya encounters an opportunity for cheap oil and credits from Venezuela in exchange for political support in a leftist alliance. Once set on this path, the process takes on a dynamic of its own, consolidating the policy switch through the attraction of certain new allies and the distancing of former allies. Unfortunately, because this is a single case study, we cannot test this hypothesis against others.

The policy-switch phenomenon has been a frequent occurrence in post-democratization Latin America, but the novelty of the Honduran case is that for the first time this switch takes place from right to left (rather than being the more common left-to-right shift). While Susan Stokes's discussion of the policy-switch phenomenon (2001) laid the initial groundwork, Daniela Campello's theory (2011, forthcoming) gives a more complete explanation of the causal mechanisms behind the policy switch itself. We see the Honduran case study's importance as being that of a test of an unpredicted, but theoretically possible development of Campello's theory. The fact that Honduras under Zelaya fits with the predictors empirically identified and exhaustively tested by Campello is instructive as a pattern-matching exercise, and our case study corroborates the explanatory validity of Campello's theory.

Furthermore, it broadens the field of research on the possibility of observing a reverse policy switch in other countries, particularly during moments of relative fragility and high risk for promarket international actors (for example, the USA, European Union, IMF, and World Bank). For scholars interested in Venezuelan politics and the ALBA countries, it may be fruitful to investigate the possibility of observing similar phenomena in small Caribbean islands such as Dominica, San Vicente and the Grenadines, and Antigua and Barbuda at the time of their entry to the ALBA agreement. It may also be worth investigating the possibility of whether other international actors 
may be playing a similar role to Venezuela's in other regional contexts, such as, maybe, China in its ongoing expansion on the African continent.

For scholars focused on Honduran politics, it will be beneficial to assess the likelihood of a realignment of the country's political system with the introduction of the new broad-based Liberty and Refoundation Party (Partido Libertad y Refundación (Libre)), a leftist party that has evolved out of the FNRP. Zelaya's ousting seems to have opened a deeper hegemonic crisis in the country. It is possible to imagine that the recent authoritarian reversal of Honduran politics could bring broad political reform to the country, amplifying the ideological spectrum of options available to the electorate and contributing to a better quality democracy. This is, ironically precisely what Zelaya proposed (Llanos and Marsteintredet, 2010a: 236) under his 'Poder Ciudadano' motto and through a Constituent Assembly ${ }^{22}$ - which ultimately led to his toppling.

\section{Acknowledgements}

Preliminary versions of this paper were presented at the 5th Congress of the Latin American Political Science Association, Buenos Aires 2010 and at the XXIX International Congress of the Latin American Studies Association, Toronto 2010. The authors would like to thank Nathan Thompson for the language revision of the manuscript. We would also like to thank Peter Peetz for sending us a scanned copy of his article; Daniela Campello for allowing us to read her new, forthcoming paper; and the anonymous reviewers for the various comments to the previous versions of this paper that allowed us to enhance it significantly.

\section{Notes}

1. Stokes's study does not use the terms 'left' and 'right' to characterize political orientation. Instead, she discusses, on the one hand, campaigns and policies oriented toward 'economic security,' which she equates with 'job creation, industrial policy, and a gradualist approach to inflation stabilization' (that is, left-of-center policies); on the other hand, she refers to campaigns and policies oriented toward 'economic efficiency,' equated with 'reducing the size of the state, privatizing state-owned enterprises, and opening trade' (that is, right-of-center policies) (Stokes, 2001: 25). In the Latin American post-democratization context, however, the terms chosen by Stokes are interchangeable here with 'left,' 'left of center,' and 'leftist' and with 'right' and 'right of center,' respectively.

2. Llanos and Marsteintredet (2010b: 180) consider it to be one of the most negative campaigns in the country's history.

3. That is the struggle against criminal gangs, which are very active in Central America.

4. The Zelayas, of Basque origin, are longtime members of the Honduran elite whose family members have held key positions in the judiciary, the armed forces, and at various levels of the country's political structure. Zelaya's father, also named Manuel Zelaya, was convicted for participation in the assassination of two priests and thirteen peasant activists, killed in 1975 while marching in demand of land at the Los Horcones farm, a Zelaya family property (see Ortiz de Zarate, 2011). Manuel Zelaya, Sr., was sentenced to twenty years in jail, but served only two years of the sentence due to an amnesty decree signed by the military dictatorship then ruling the country. The family has always claimed his innocence, but even if true, the fact that he was freed by a high-level pardon demonstrates how well connected the family is among the country's elite.

5. In January 2007, the Inter-American Development Bank (IADB) pardoned US\$1.4 billion of Honduran debt. Although this debt relief was due to Honduras having previously qualified for it by fulfilling the 
requirements of the HIPC-PRS process, Zelaya's government did lobby the IFIs for quicker enactment. In 2008, the US government extended (for 18 months) the Temporary Protection Status of Honduran immigrants, which had been conceded after the devastation caused by hurricane Mitch in Honduras in 1998.

6. In an environment of increasing fuel prices (oil had reached US\$65 and diesel US\$92 a barrel), Maduro declared an energy emergency in September 2005, and increased fuel prices in the country by between 7.9 and 19.7 percent. This triggered a massive demonstration by taxi drivers that paralyzed the capital and forced the government to reinstate fuel subsidies and compensatory measures. With pressure building to reform the country's energy sector, the government also formed a Commission of Notables, the body which proposed the international competitive bidding process that finally came to fruition during the Zelaya administration in 2006 (Murillo Parrales, 2006; Pirker and Núñez, 2010).

7. According to Ortiz de Zarate (2011): 'The presidents agreed that Venezuela would start providing Honduras with 20.000 barrels of fuel a day for two years. The client would commit to buying from the provider $100 \%$ of fuel-oil (bunker) for electric generation, $30 \%$ of gasoil and $30 \%$ of the gasoline consumed. In turn, Venezuela would take over a biennial debt of 750 million dollars, of which Honduras would repay $60 \%$ on delivery in cash, and the remaining $40 \%$ in 23 years and with an interest rate of $1 \%$ per year. Furthermore, Chávez accepted [that] his new Central American partner [would] pay-off $40 \%$ of the debt in agricultural goods.' See also Cordero (2009: 14).

8. For a description of the distinctive traits of ALBA's main countries (Venezuela, Ecuador, and Bolivia), as compared with other more moderate left-wing governments in Latin America, see Ellner (2012). For an analysis of how Hugo Chávez assumed the role of heir to Fidel Castro's position as symbolic leader of the Latin American radical left, see Hoffmann (2009).

9. It would later be joined by Ecuador, Saint Vincent and the Grenadines, and Antigua and Barbuda in June 2009.

10. This went as far as affirming that ALBA consisted of an 'ideological political and military alliance that conspires against the freedom of trade and the exercise of individual liberties' (Ortiz de Zarate, 2011).

11. The vice-president did not actually participate in the primaries as he was barred from doing so by legal rules. Instead, Vice-President Santos appointed Mauricio Villeda as his proxy candidate in the primaries, after whose victory he resigned as vice-president and took over as the PLH's candidate (Llanos and Marsteintredet, 2010b; Taylor-Robinson, 2009).

12. Because the ultimate referendum was to be held during the general election, which already was to have three ballot boxes (or urnas in Spanish) for the presidential, legislative, and municipal elections, it became popularly known as the Cuarta Urna (Fourth Urn).

13. For a more detailed description of the collapse of Zelaya's presidency and the Honduran coup, see Llanos and Marsteintredet (2010a, 2010b) and Oettler and Peetz (2010). For a perspective on the coup's impact for the formation of the National Front of Popular Resistance (FNRP) as a new and important political actor, see Cálix (2010). For a description of the joint Colombian and Venezuelan mediation that enabled Zelaya to return and cleared the way for Honduras's readmission to the OAS, see Vieira (2011).

14. For the sake of comparability with the policy-switch literature, by 'leftist' we refer to the policies of 'economic security' alluded to by Stokes (2001), as opposed to the policies of 'economic efficiency' already described in note 1 above and also used by Campello (2011, forthcoming). These could also be characterized as 'non-neoliberal' and 'neoliberal' policies, which in fact was the defining axis of the leftright divide in post-democratization Latin America. We recognize that this is an oversimplification and that there is much debate on this topic in the literature. This goes, however, much beyond the scope of this article, but see, among others, Alegre et al. (2010), Castañeda (2006), Da Cruz (2008), Ellner (2012), Lanzaro (2007, 2009), Lievesley and Ludlam (2009), Pereira da Silva (2010, 2011), and Weyland et al. (2010) for examples of the current debates over the left in contemporary Latin American studies, ranging 
from discussions over the dichotomous division between a 'good' modern left and a 'bad' authoritarian one or between social democracy and populism to more nuanced typologies of the different leftist parties in the region and analyses of their actual performance once in office.

15. The following are Stokes's full set of cases (italicized years denote those cases that she coded as switches): Argentina in 1983, 1989, and 1995; Bolivia in 1985, 1989, and 1993; Brazil in 1989 and 1994; Chile in 1989 and 1993; Colombia in 1982, 1986, 1990, and 1994; Costa Rica in 1982, 1986, 1990, and 1994; the Dominican Republic in 1982, 1986, 1990, and 1994; Ecuador in 1984, 1988, and 1992; El Salvador in 1984, 1989, and 1994; Guatemala in 1985, 1990, and 1995; Honduras in 1989 and 1993; Nicaragua in 1984 and 1990; Peru in 1985, 1990, and 1995; Uruguay in 1984, 1989, and 1994; and Venezuela in 1983, 1988, and 1993. The cases of Costa Rica in 1982, the Dominican Republic in 1994, and Guatemala in 1985 and 1990 were considered by her as inconclusive and were therefore not coded.

16. The following are the cases considered by Campello (italicized years denote those cases that were coded as switches, all of which were from left to right): Argentina in 1983, 1989, 1995, 1999, and 2003; Bolivia in 1985, 1989, 1993, 1997, 2002, and 2005; Brazil in 1989, 1994, 1998, 2002, and 2006; Chile in 1989, 1993, 1999, and 2005; Colombia in 1982, 1986, 1990, 1994, 1998, 2002, and 2006; Costa Rica in 1978, 1982, 1986, 1990, 1994, 1998, 2002, and 2006; the Dominican Republic in 1982, 1986, 1990, 1994, 1996, 2000, and 2004; Ecuador in 1984, 1988, 1992, 1996, 1998, 2002, and 2006; El Salvador in 1984, 1989, 1994, 1999, and 2004; Guatemala in 1985, 1990, 1995, 1999, and 2003; Honduras in 1985, 1989, 1993, 1997, 2001, and 2005; Mexico in 1988, 1994, 2000, and 2006; Nicaragua in 1996, 2001, and 2006; Peru in 1980, 1985, 1990, 1995, 2001, and 2006; Uruguay in 1984, 1989, 1994, 1999, and 2004; and Venezuela in 1983, 1988, 1993, 1998, 2000, and 2006.

17. For the full results of her statistical tests, see Campello (forthcoming).

18. Maquilas are factories that import raw materials on a tariff-free basis for assembly, processing, or manufacturing and then export the final product. They are typically labor-intensive units, benefiting from cheap labor costs and free-trade agreements.

19. When trying to become the PLH's candidate for the 2005 elections, Zelaya founded a new faction inside the party called Movimiento Esperanza Liberal (Liberal Hope Movement), a name chosen so that its acronym, MEL, would echo the nickname by which he is most well known (Ortiz de Zarate, 2011).

20. Information here is drawn mainly from the political biography compiled by Ortiz de Zarate (2011) for the Catalonia-based Fundació CIDOB. This document is available at http://www.cidob.org/es/documentacion/ biografias_lideres_politicos/america_central_y_caribe/honduras/manuel_zelaya_rosales.

21. In analyzing the Honduran political environment in 2006, the cost of fuel is the only issue identified by Julieta Castellanos (2006) with the capacity to spark broad-based mobilization.

22. Ideas about what the new constitution would look like and what the Constituent Assembly should do were vague, and because the initiative was aborted with the coup it is impossible to know for sure what the consequences would have been for the Honduran political system. Zelaya's main proposal was the enactment of more powerful mechanisms of participatory and direct democracy, which if enacted could indeed have put the country constitutionally closer to the model adopted by Venezuela, Ecuador, and Bolivia (see Pérez Flores et al., 2010). The opposition, which by this point included most of the PLH, claimed that Zelaya's hidden agenda was to get himself reelected. The opposition used this as one of the main arguments to justify his ousting. Although it cannot be known for sure whether the new constitution would have allowed a second term (or more), this was never an official agenda item for the Constituent Assembly. But as the Constituent Assembly was scheduled to be elected and seated at the same time as Zelaya's successor, it weakens the opposition's claim that the Constituent Assembly and constitution was a Chavista-like power grab on the part of Zelaya. 


\section{References}

Ajenjo Fresno N (2007) Honduras: Nuevo gobierno liberal con la misma agenda política. Revista de Ciencia Politica (Santiago), Special Issue 27: 165-81.

Alegre P, et al. (2010) Las izquierdas latinoamericanas: De la oposición al gobierno. Buenos Aires: CLACSO.

Altmann Borbón J (2009) El ALBA, Petrocaribe y Centroamérica: ¿intereses comunes? Nueva Sociedad (219): $127-44$.

Cálix Á (2010) Honduras: De la crisis política al surgimiento de un nuevo actor social. Nueva Sociedad (226): 34-51.

Campello D (2011) The politics of redistribution in less developed democracies: Evidence from Brazil, Ecuador and Venezuela. In: Blofield M (ed.) The Great Gap: Inequality and the Politics of Redistribution in Latin America. University Park: Penn State University Press.

Campello D (forthcoming) The politics of financial booms and crises: Evidence from Latin America. Comparative Political Studies 47(5).

Castañeda JG (2006) Latin America's left turn. Foreign Affairs 85(3): 28-43.

Castellanos J (2006) Honduras: Gobernabilidad democrática y sistema político. Nueva Sociedad, Special Issue.

Cordero JA (2009) Honduras: Recent economic performance. Available at: http://www.cepr.net/documents/ publications/honduras-2009-11.pdf (accessed 27 March 2012).

Cuesta J (2007) Political space, pro-poor growth and poverty reduction strategy in Honduras: A story of missed opportunities. Journal of Latin American Studies 39(2): 329-54.

Da Cruz AS Jr (2008) Fazendo o Caminho ao Andar: Aportes introdutórios para a caracterização da Esquerda Latino-Americana no começo do século XXI. In: Soares de Lima MR (ed.) Desempenho de governos progressistas no Cone Sul: Agendas alternativas ao neoliberalismo. Rio de Janeiro: Edições IUPERJ, pp. 147-76.

Dewachter S and Molenaers N (2011) Who takes a seat at the pro-poor table? Civil society participation in the Honduran Poverty Reduction Strategy. Latin American Research Review 46(3): 112-32.

Dooley M and Hutchison M (2009) Transmission of the US subprime crisis to emerging markets: Evidence on the decoupling-recoupling hypothesis. Journal of International Money and Finance 28(8): 1331-49.

Drake P (1992) Comment. In: Dornbusch R and Edwards S (eds) The Macroeconomics of Populism in Latin America. Chicago, IL: University of Chicago Press, pp. 35-40.

Ellner S (2012) The distinguishing features of Latin America's new left in power. Latin American Perspectives 39(1): 96-114.

Gerring J (2012) Social Science Methodology: A Unified Framework, 2nd edn. New York: Cambridge University Press.

Grandin G (2010) Honduras, Obama and the region's new right. LASA Forum 41(1): 8-11.

Hoffmann B (2009) Charismatic authority and leadership change: Lessons from Cuba's post-Fidel succession. International Political Science Review 30(3): 229-48.

Index Mundi (2012) Current account balance. Available at: http://www.indexmundi.com/honduras/current_ account balance.html (accessed 20 March 2012).

Klesner JL (2006) El año electoral decisivo de América Latina. Foreign Affairs en Español 6(2). English version available at: http://www2.kenyon.edu/Depts/PSci/Fac/klesner/Latin_America_Pivotal_Electoral_ Year.pdf.

Komives K (2011) Institutionalizing social accountability? Participation and the PRS process in Bolivia, Honduras and Nicaragua. European Journal of Development Research 23(2): 302-18.

Lanzaro J (2007) Gobiernos de izquierda en América Latina: Entre el populismo y la social democracia - Una tipología para avanzar en el análisis comparado. Análises de Conjuntura OPSA 3(12).

Lanzaro J (2009) La social democracia criolla. Análises de Conjuntura OPSA 5(3).

Lievesley G and Ludlam S (eds) (2009) Reclaiming Latin America: Experiments in Radical Social Democracy. London and New York: Zed Books. 
Llanos M and Marsteintredet L (2010a) Epilogue: The breakdown of Zelaya's presidency: Honduras in comparative perspective. In: Llanos M and Marsteintredet L (eds) Presidential Breakdowns in Latin America. New York: Palgrave Macmillan, pp. 229-37.

Llanos M and Marsteintredet L (2010b) Ruptura y continuidad: La caída de «Mel» Zelaya en perspectiva comparada. América Latina Hoy 55: 173-97.

Meza V (2006) El caso de Honduras. In: Coloquio regional sobre los recientes procesos electorales en Centro América y sus consecuencias. San José, Costa Rica: Centro de Investigación y Adiestramento Político Administrativo. Available at: http://ciapa.org/pdf/Victor_Meza.pdf.

Moreno I (2007) El Presidente en su laberinto (o en su 'patastera'). Revista Envío 305. Available at: http:// www.envio.org.ni/articulo/3622 (accessed 24 May 2011).

Moreno I (2009) Mal comenzó el último año de Zelaya. Revista Envío 324. Available at: http://www.envio. org.ni/articulo/3976 (accessed 21 May 2011).

Murillo Parrales Á (2006) Cómo Honduras enfrenta crisis energética. El Nuevo Diario. Available at: http:// impreso.elnuevodiario.com.ni/2006/07/21/opinion/24624 (accessed 23 March 2012).

Oettler A and Peetz P (2010) Putsch in Honduras: Störfall in der defekten Demokratie. Internationale Politik und Gesellschaft 1: 82-95.

Ortiz de Zarate R (2011) Biografía Manuel Zelaya Rosales. Biografías Líderes Politicos. Available at: http:// www.cidob.org/es/documentacion/biografias_lideres_politicos/america_central_y_caribe/honduras/ manuel_zelaya_rosales (accessed 22 March 2012).

Payne JM, Zovatto D and Mateo Díaz M (2007) Democracies in Development: Politics and Reform in Latin America, expanded edn. Washington, DC: IDB.

Paz Aguilar E (2006) Honduras: Elecciones 2005. In: Coloquio regional sobre los recientes procesos electorales en Centro América y sus consecuencias. San José, Costa Rica: Centro de Investigación y Adiestramento Político Administrativo. Available at: http://www.ciapa.org/pdf/E Paz.pdf.

Peetz P (2009) ¿De hacendado a revolucionario? Mel Zelaya y el giro a la izquierda del gobierno hondureño. Iberoamericana 9(33): 181-6.

Pereira da Silva F (2010) Esquerdas latino-americanas: Uma tipologia é possível? Oikos 9(2): 121-40.

Pereira da Silva F (2011) Vitórias na crise: Trajetórias das esquerdas latino-americanas contemporâneas. Rio de Janeiro: Ponteio.

Pérez Flores F and Kfuri R (2011) Aliança Bolivariana ou a integração como projeto hegemônico. In: Vadell J and Campos T (eds) Os novos rumos do regionalismo e as alternativas políticas na América do Sul. Belo Horizonte: PUC Minas, pp. 390-417.

Pérez Flores F, Cunha Filho CM and Coelho AL (2010) Participación ampliada y reforma del Estado: Mecanismos constitucionales de democracia participativa en Bolivia, Ecuador y Venezuela. Observatorio Social de América Latina 11(27): 73-95.

Pirker K and Núñez O (2010) Cuatro hipótesis y un corolario en torno al golpe de estado en Honduras. Nostromo - Revista Crítica Latinoamericana 3: 113-30.

Pitkin HF (1972) The Concept of Representation. Berkeley: University of California Press.

Roberts KM (1995) Neoliberalism and the transformation of populism in Latin America: The Peruvian case. World Politics 48(1): 82-116.

Rusiñol P (2009) El oligarca que cambió de bando. Público 2(637): 12.

Stokes SC (2001) Mandates and Democracy: Neoliberalism by Surprise in Latin America. Cambridge: Cambridge University Press.

Tarrow S (1994) Power in Movement: Social Movements and Contentious Politics, 1st edn. Cambridge: Cambridge University Press.

Taylor-Robinson MM (2006) La política hondureña y las elecciones de 2005. Revista de Ciencia Politica (Santiago) 26(1): 114-26.

Taylor-Robinson MM (2009) Honduras: una mezcla de cambio y continuidad. Revista de Ciencia Política (Santiago) 29(2): 471-89. 
Vieira AL dos S (2011) A parceria improvável: Colômbia e Venezuela viabilizam acordo de reconciliação hondurenha. Available at: http://observatorio.iesp.uerj.br/pdfs/139_artigos_2011_05_24_Colombia.pdf.

Weyland K, Madrid RL and Hunter W (eds) (2010) Leftist Governments in Latin America: Successes and Shortcomings, 1st edn. New York: Cambridge University Press.

Williamson J (1990) What Washington means by policy reform. In: Williamson J (ed.) Latin American Adjustment: How Much Has Happened? Washington, DC: Institute for International Economics (US). Available at: http://www.iie.com/publications/papers/paper.cfm?ResearchID=486 (accessed 4 April 2012).

\section{Biographical notes}

Clayton M. Cunha Filho is PhD candidate in Political Science at the Institute for Social and Political Studies from Rio de Janeiro State University (IESP-UERJ). He is a researcher at the South American Political Observatory (OPSA) and has published several articles on Latin American politics and democratization issues in books and journals such as Observatorio Social de América Latina (OSAL) and Latin American Politics (LAP).

André Luiz Coelho is a Professor of Political Science and International Relations at the Federal University of Rio de Janeiro State (UNIRIO) and at the La Salle University Center. He has published several articles on political crises and presidential stability, social movements and political parties in Latin America in books and journals as Observatorio Social de América Latina (OSAL) and Revista Politica.

Fidel I. Pérez Flores is PhD Candidate in Political Science at the Institute for Social and Political Studies from Rio de Janeiro State University (IESP-UERJ). His research interests include Latin American political processes in the fields of Foreign Policies, Institutions of Participatory Democracy and 21th Century Left Governments. He is a researcher at the South American Political Observatory (OPSA) and has published articles in journals and books about Venezuelan contemporary politics. 